\title{
Paulo Coelho's The Alchemist: the Mnemonics of Life Management Skills
}

\author{
Dr Rajendra Kumar Dash \\ Assistant Professor (English), School of Humanities, KIIT University, Bhubaneswar, Odisha, India
}

\begin{abstract}
Paulo Coelho's The Alchemist has been hailed as a book that has transformed the lives of millions of people for the better. In fact, it is more a self-help book than a novel. In it, Coelho has focused on the art of living: how to make life interesting by following one's dream. He asserts that one has to discover one's personal legend or the very purpose of being. With the support of the philosophy and psychology of Alchemy, which is basically an art as well as science of personal transformation, the underlying idea being as lead is transformed/evolved into gold (i.e., lead's full potential), similarly all human beings are capable of selfactualization or realizing their full potential. Coelho believes that paying heed to one's unconscious, which manifests itself in forms like dreams, myths, omens and symbols, one should undertake the journey of life with love and care. One has to pay the price for one's dream. The novelist lays emphasis on taking decisions: one should not be deterred by various formidable obstacles that come one's way. Coelho claims that actually the greatest secret of success in life is love, for it is at the root of personal transformation and collective evolution.
\end{abstract}

Keywords: alchemy, Beginner's Luck, Life management, personal calling, personal transformation, Personality development, self actualization

\section{Introduction}

What is common between Ernest Hemingway's The Old Man and the Sea, Hermann Hesse's Siddhartha, and Paulo Coelho's The Alchemist? It is the protagonist's journey through a maze of illusions and bizarre experiences of life, so characteristic of the novice or the perplexed, that renders these novels interesting; what's more the protagonist's ability to withstand the vicissitudes across the path calmly and consistently to actualize their potentialities makes these novels to be seen as formulae for success. As of Coelho's The Alchemist, it is a treatise on life management demonstrated through a story of an ordinary, poor boy from Andalusia, who pursues his dream which requires him to seek out the hidden treasure in the pyramids of Egypt. It is a scintillating tale of an ordinary individual becoming what he is capable of or realizing his destiny.

\section{The Hero's Journey}

Santiago leaves his home behind and becomes a shepherd so that he could travel and know the world better. The novel narrates his journey, which becomes a transformative one ultimately, and at the end he gets the treasure which was hard to attain. It is intended to be a self-help book like Shiv Khera's You Can Win, Anthony Robbins' Awake the Giant within You or Deepak Chopra's The Seven Spiritual Laws of Superheroes: Harnessing Our Power to Change the World. But unlike them all, Paulo Coelho has exploited the ideas of Alchemy to lay out the blue print of success of life. Alchemy underlies the belief that base metals like lead can be transmuted into gold, the perfect matter, and ordinary, flawed human beings can be self-actualized beings. The Alchemist narrates the story of success which exhibits how to set the goal of life and how to pursue it successfully. The success of the novel as a mnemonics of the art of following one's dream successfully has been acknowledged by the fact that millions of people have transformed their lives for the better by adopting the formula of success laid out in The Alchemist.

\section{Character is Destiny}

Paulo Coelho lays emphasis on the fact that character is destiny. In other words, a person can and does influence his or her destiny in a very significant way. The most important step in getting the best out of life is to set the goal, which should be the very reason of our existence. In The Alchemist, this is more famously known as the personal legend. When Santiago decides to travel all the distance to Egypt, he is not fully convinced. At this time an alchemist (the king of Salem) appears to tell him that having a dream makes life interesting and one must find out one's personal legend and then follow it to its logical end - its realization. He tells Santiago, "It's what you have always wanted to accomplish. Everyone, when they are young, knows what their Personal 
Legend is." He continues, "At that point in their lives, everything is clear and everything is possible. They are not afraid to dream, and to yearn for everything they would like to see happen to them in their lives" (Coelho 15). Most importantly, he asserts "To realize one's Personal Legend is a person's only real obligation" (ibid). For Santiago, to find the treasure is his personal legend and he is convinced of that. However, there is many an obstacle to overcome in realizing one's dream.

\section{The Secret of Overcoming the Obstacles to Success}

The old king of Salem reveals that when one is young, one knows what one's personal legend is. It endows one with enthusiasm and the gusto to accomplish something. When one is young, one finds it intuitionally. Commonsense is enough to understand one's personal legend; however, common sense is not very common. After one has recognized one's personal legend, one needs to be aware of one's strengths, weaknesses, opportunities, and threats. Paulo Coelho recognizes there are four obstacles on the path to dream realization. The first obstacle in realizing one's personal legend is negativity, which comes from the pressures from parents, teachers, tradition, and expectations from the society. One is told that one's dream is not possible or it can't be done. In Coelho's words, "First, we are told from childhood onwards that everything we want to do is impossible. We grow up with this idea, and as the years accumulate, so too the layers of prejudice, fear and guilt. There comes a time when our personal calling [legend] is so deeply buried in our soul as to be invisible. But it's still there" (viii). If one follows one's dream with courage of conviction, then the second obstacle is love. The follower of the legend fears that he or she may hurt the loved ones. "We know what we want to do," observes Coelho, "but we are afraid of hurting those around us by abandoning everything in order to pursue our dream. We do not realize that love is just a further impetus, not something that will prevent us going forward, and those who genuinely wish us well want us to be happy and are prepared to accompany us on that journey" (viii). After accepting love as a stimulus in the journey, the third obstacle that visits the traveler is the fear of failure. One encounters a number of difficulties on the way and it appears that one may not succeed. One may be tempted to give up one's dream in face of the "insurmountable" hardships. One may stumble several times but should not quit. Coelho says the secret of success is to be unperturbed by the fall and get up once again. If somebody overcomes the third obstacle (i.e., the fear of failure), the fourth obstacle is the guilt of success. This happens when one is too close to realizing one's dream or one's personal legend. Coelho beautifully explains this phenomenon: "Having disinterred our dream, having used the power of love to nurture it and spent many years living with the scars, we suddenly notice that what we always wanted is there, waiting for us, perhaps the very next day. Then comes the fourth obstacle: the fear of realizing the dream for which we have been fighting all our lives" (Coelho ix). If it is so, how can one be successful?

Melchizedek, the old king of Salem, assures Santiago that "when you want something, all the universe conspires in helping you to achieve it." Everything is written in the Soul of the World. What matters is to know how to read the omens, which would reveal the secret of everything. He states, "In order to find the treasure, you will have to follow the omens. God has prepared a path for everyone to follow. You just have to read the omens that he left you" (Coelho 20). An omen is a phenomenon that is believed to foretell the future. Omens are actually neither good nor bad. They are a sort of symbols which indicate what would happen in future but all the same one could manipulate the outcomes by preventive action or modify the very nature of things. Coelho is of the opinion that the ability to read the omens can help one in one's journey for the dream. Both intuition and experience are required for this. According to the old man, "Intuition is really a sudden immersion of the soul into the universal current of life."

\section{Following the Personal Legend}

Now coming to Santiago, we see him in an existential situation. He has left the comforts of home and he has provided one-tenth of his sheep to Melchizedek to help him make a decision whether to pursue his dream or not. The wise man tells him everything in life has a price and more so a dream. The wisdom he barters with the boy is that he should listen to his heart and follow the omens. "When you want something with all your heart," counsels the old man to Santiago, "that's when you are closest to the Soul of the World. It's always a positive force." He further tells the boy that "the soul of the world is nourished by people's happiness. And also by unhappiness, envy, and jealousy. To realize one's destiny is a person's only obligation. All things are one." $\mathrm{He}$ is also told that in his quest for the hidden treasure in the pyramids, he will be assisted by Beginner's Luck, which is when one begins a work he savours the taste of success. The old man also tells him the miracle involved in the power of love, which helps one accomplish the otherwise impossible. As the boy proceeds in his journey, now with the wisdom of the old wise guide, he experiences the truth involved in the latter's words, for he gets cheated of all his money (that he had accumulated by selling his sheep) by a local youth ignoring the bar tender's nonverbal cues not to trust that guy. Now that all his money gone, he has to start from the scratch. However, he becomes sadder but wiser, for he has experienced how to read the omens. 
Now that he is a pauper, he offers himself to do menial jobs with a crystal merchant at Tangiers. He comes to use his uncanny ability to read the omens and soon his love, devotion, and hard work leave the merchant richer and himself able to save enough money to start for the pyramids. On his way to the pyramids through the Sahara desert, he befriends an Englishman. The latter is bound for the Al-Fayoum island which is fabled for a two hundred year alchemist. The English man wants to learn from the alchemist about the universal language (i.e. Love) though he very much doubted whether alchemists were at all able to produce the Philosopher's Stone, which could turn base metals such as lead and bestow the partaker with prolonged life through its Elixir of Life. The alchemical books do not impress the boy much. However, they agree that omens are a powerful language and through it one could get help to realize one's dream. On the way, Santiago learns that all things in the universe are connected and therefore even small and ordinary things make sense. It is love that enables one to see and understand the creation. He feels that the "closer one gets to realizing his Personal Legend, the more that Personal Legend becomes his true reason for being." He comes to know that alchemy believes that "Everything on earth is being continuously transformed, because the earth is alive ... and it has a soul. We are part of that soul, so we rarely recognize that it is working for us. But in the crystal shop you probably realized that even the glasses were collaborating in your success." The boy has perhaps understood alchemy better than the English man who doubted the very existence of the Philosopher's Stone. Coelho suggests that alchemy was perhaps not the Personal Legend of the English man. Love, devotion, and dedication are the tools of success. The method of the English man differed from the boy, for "Everyone has his or her own way of learning things."

Paulo Coelho's blue print for success lays emphasis on having a dream, a Personal Legend, and the courage of conviction to follow it to its logical end, that is, its realization. He highlights the need of having intuition and experience and the understanding that life is very simple, it is we that make our lives complex. He values qualities like setting goals, making decisions and being accountable for it, solving problems in a practical manner, and not hesitating to take detours in one's journey which he equates with life. Significantly enough, he never precludes the need of taking the help of others but emphasizes that one must seek out one's own salvation. Let us see how Santiago achieves his Personal Legend.

\section{Love is life!}

The otherwise peaceful desert erupts into violence as the tribes are at war for balance of power and maintaining hegemony. Conflict is often a force to reckon with and an individual must learn to keep his cool when everything around him seems to be uncertain. The caravan that has boarded so far Santiago and the Englishman reaches the Al-Fayoum island, the land of the alchemist. While helping the Englishman find the alchemist, Santiago gets united with Fatima, a girl of the island, and they fall in love. Coelho dramatizes the second obstacle in Santiago's life-Love. He is ready to settle in the island marrying Fatima and becoming the counselor of the island but for the alchemist's warning that he would never realize his Personal Legend. As per the advice of the alchemist, who finds a ready disciple in Santiago rather than in the Englishman, Santiago seeks the permission of Fatima to resume his journey for the treasure, his Personal Legend. Fatima bids his love farewell and says that she will eagerly wait for his return. The novelist observes that "When we love, we always strive to become better than we are. When we strive to become better than we are, everything around us becomes better too." With the permission of Fatima, Santiago leaves for the pyramids which are only a few hours' away to seek and find his hidden treasure.

On the way, Santiago urges the alchemist to teach him alchemy, the art of transmutation. The alchemist tells him that it comprises simple truth that everything in the world had a soul and they would evolve till they became perfect. He further tells him to listen to his heart. The conversation between the boy and his mentor is reproduced:

"Why do we have to listen to our hearts?" the boy asked, when they had made camp that day.

"Because, wherever your heart is, that is where you'll find your treasure."

"But my heart is agitated," the boy said. "It has its dreams, it gets emotional, and it's become passionate over a woman of the desert. It asks things of me, and it keeps me from sleeping many nights, when I'm thinking about her."

"Well, that's good. Your heart is alive. Keep listening to what it has to say" (Coelho 84)

The alchemist tells the boy the secret to calm his heart when the boy complains that he finds it difficult:

"My heart is afraid that it will have to suffer," the boy told the alchemist one night as they looked up at the moonless sky.

"Tell your heart that the fear of suffering is worse than the suffering itself. And that no heart has ever suffered when it goes in search of its dreams, because every second of the search is a second's encounter with God and with eternity" (Coelho 85) 
Before taking leave from the boy, the alchemist initiates him with yet another secret:

What you still need to know is this: before a dream is realized, the Soul of the World tests everything that was learned along the way. It does this not because it is evil, but so that we can, in addition to realizing our dreams, master the lessons we've learned as we've moved toward that dream. That's the point at which most people give up. It's the point at which, as we say in the language of the desert, one 'dies of thirst just when the palm trees have appeared on the horizon.' (Coelho 87)

The most important thing that happens before the departure of the alchemist that Santiago is required to prove that he can do alchemy. On their way to the pyramids, they are apprehended by a group of tribal people and the alchemist tells them that Santiago can turn himself into wind. The condition is do or die. Central to the concept of alchemy, one could transmute elements. Invoking the power of love, the boy summons all the elements--wind, the sun, so on and so forth---and they enable him to prove himself. With a scene of fantasy, Coelho beautifully dramatizes the transformative power of love. Now after two hours journey, when his mentor leaves him on his path to perfection, Santiago realizes through omen that the hidden treasure is much within himself and without (at the place where he dreamt of it). At the end of his journey, Santiago realizes the Self or to use Carl Jung's phrase becomes 'individuated'.

\section{Conclusion}

Paulo Coelho's The Alchemist has been hailed as a book that has transformed the lives of millions of people for the better. In fact, it is more a self-help book than a novel. In it, Coelho has focused on the art of living: how to make life interesting by following one's dream. He asserts that one has to discover one's personal legend or the very purpose of being. With the support of the philosophy and psychology of Alchemy, which is basically an art as well as science of personal transformation, the underlying idea being as lead is transformed/evolved into gold (i.e., lead's full potential), similarly all human beings are capable of selfactualization or realizing their full potential. Coelho believes that paying heed to one's unconscious, which manifests itself in forms like dreams, myths, omens and symbols, one should undertake the journey of life with love and care. One has to pay the price for one's dream. The novelist lays emphasis on taking decisions: one should not be deterred by various formidable obstacles that come one's way. Coelho claims that actually the greatest secret of success in life is love, for it is at the root of personal transformation and collective evolution. The lessons of life that The Alchemist teaches are many: life is a boredom without having a dream; it requires a lot of courage and strength of character to consistently pursue one's dream in the face of odds and temptations; the importance of listening to one's heart; the significance of reading the omens and learning through doing (i.e., action); taking decision and remaining accountable for it; solving problems with fortitude; and most importantly, realizing the enormous power of love. In short, The Alchemist is a mnemonic of life management.

\section{Reference}

